[Case Report]

\title{
Fulminant Type 1 Diabetes with Diversity in Peripheral Blood Lymphocytes: A Case Report
}

\author{
Akira Kurozumi*, Yosuke Okada, Yusuke Miyazaki, Shingo NakaYamada and Yoshiya Tanaka \\ First Department of Internal Medicine, School of Medicine, University of Occupational and Environmental Health, Japan. \\ Yahatanishi-ku, Kitakyushu 807-8555, Japan
}

\begin{abstract}
A 29-year-old woman was admitted to our hospital for treatment of fulminant type 1 diabetes (FT1D) with diabetic ketoacidosis. The phenotype of peripheral blood lymphocytes was analyzed using an 8-color flow cytometer. An analysis of the CD4-positive T cells showed a tendency for higher proportions of effector and central memory $\mathrm{T}$ cells and a normal proportion of regulatory $\mathrm{T}$ (Treg) cells, compared to healthy control. An analysis of B cell differentiation showed higher proportions of switched memory B cells and plasmablasts. The differences in lymphocyte phenotypes between our case and previously reported cases suggest a diversity of FT1D pathology.
\end{abstract}

Keywords : fulminant type 1 diabetes, flow cytometry, peripheral blood lymphocytes.

(Received September 2, 2019, accepted October 15, 2019)

\section{Introduction}

Fulminant type 1 diabetes (FT1D), a subtype of type 1 diabetes reported by Imagawa et al in 2000 [1, 2], is characterized by rapid deterioration of pancreatic $\beta$-cell function. According to a literature review on the diagnostic criteria used for FT1D, islet-related autoantibodies, such as antibodies to glutamic acid decarboxylase (GAD), are generally absent in FT1D, which differentiates it from the classic acute-onset autoimmune type 1 diabetes.

Aida et al [3] reported that immunohistochemical staining of pancreatic lesions in an autopsy of a FT1D case demonstrated the presence of marked infiltration of macrophages and CD8-positive T cells in and around the pancreatic islets. To the best of our knowledge, there are only a few reports of immunological findings in FT1D. We herein report a case of FT1D that showed abnormal differentiation of lymphocytes, in contrast to the findings reported previously [3].

\section{Case Report}

The patient was a 29-year-old woman. Her body weight at age 20 was $45 \mathrm{~kg}$ (BMI $20.5 \mathrm{~kg} / \mathrm{m}^{2}$ ). She became pregnant at the age of 24 and 27 years, but neither developed hyperglycemia during these pregnancies nor showed signs of glucose intolerance or perinatal abnormalities. The patient was referred to a general hospital for further examination of upper abdominal pain and general fatigue, anorexia, thirst and weight loss $(6 \mathrm{~kg}) 1$ month before the current presentation. She was admitted to a hospital for suspected acute pancreatitis, and was found to have high levels of pancreatic exocrine enzymes (blood amylase 288 IU/l, urinary amylase $1673 \mathrm{IU} / l$ ) and pancreas enlargement on abdominal computed tomography (CT). She was discharged 10 days later, after improvement of the

*Corresponding Author: Akira Kurozumi, MD, First Department of Internal Medicine, School of Medicine, University of Occupational and Environmental Health, Japan. 1-1 Iseigaoka, Yahatanishi-ku, Kitakyushu 807-8555, Japan. Tel: +81-93-603-1611, Fax: +81-93-691-9334, E-mail: akira@ med.uoeh-u.ac.jp 
clinical features in response to fasting and antibiotics and nafamostat mesilate. During hospitalization, her postprandial plasma glucose was $200^{-300 ~} \mathrm{mg} / \mathrm{dl}$, and ketone bodies were positive on urine tests (blood gas analysis was not conducted). However, no particular treatment was provided for the hyperglycemia because the hemoglobin $\mathrm{A} 1 \mathrm{c}(\mathrm{HbA1c})$ was only 5.4\%. Instead, she was referred to the Department of Gastroenterology at our hospital for further management of pancreatitis. On admission, her postprandial plasma glucose level was $445 \mathrm{mg} / \mathrm{d} l$, urine ketone $3+$, with metabolic acidosis in the blood gas analysis $(\mathrm{pH} 7.177$, base excess -17.6). Accordingly, she was transferred to our department for the treatment of diabetic ketoacidosis (DKA). Apart from the above illness, she had an otherwise normal medical history, and the family history was negative apart from a maternal grandmother with type 2 diabetes.

On admission to our department, her body weight was $31.7 \mathrm{~kg}$ (BMI $\left.14.5 \mathrm{~kg} / \mathrm{m}^{2}\right)$. She was lean with $\mathrm{ke}-$ tone odor and dry skin. The laboratory findings on admission are listed in Table 1. Venous blood gas analysis showed remarkable metabolic acidosis and positive urinary ketone bodies. With regard to diabetes-related tests: her fasting plasma glucose level was $331 \mathrm{mg} /$ $\mathrm{d} l$, postprandial plasma glucose level $473 \mathrm{mg} / \mathrm{d} l$, and

Table 1. Laboratory data on the admission of the patient

\begin{tabular}{|c|c|c|c|c|c|}
\hline \multicolumn{2}{|l|}{$\mathrm{CBC}$} & \multicolumn{2}{|l|}{ Biochemistry } & \multicolumn{2}{|l|}{ Diabetes-related } \\
\hline $\mathrm{WBC}\left(/ \mathrm{mm}^{3}\right)$ & 11300 & $\mathrm{TP}(\mathrm{g} / \mathrm{d} l)$ & 8.0 & $\mathrm{FPG}(\mathrm{mg} / \mathrm{d} l)$ & 331 \\
\hline Neutrophils (\%) & 77.8 & $\operatorname{Alb}(\mathrm{g} / \mathrm{d} l)$ & 5.2 & PPG $(\mathrm{mg} / \mathrm{d} l)$ & 473 \\
\hline Eosinophils (\%) & 0.1 & AST (IU/l) & 16 & HbA1c $(\%)$ & 9.6 \\
\hline Basophils (\%) & 0.8 & $\operatorname{ALT}(\mathrm{IU} / l)$ & 18 & 24h urine-CPR ( $\mu \mathrm{g} /$ day) & 5.3 \\
\hline Lymphocytes (\%) & 16.1 & $\gamma$-GTP $(\mathrm{IU} / l)$ & 12 & ACR (mg/gCre) & 3.9 \\
\hline Monocytes (\%) & 5.2 & $\mathrm{LDH}(\mathrm{U} / l)$ & 130 & GAD-Ab $(\mathrm{U} / \mathrm{m} l)$ & $<5.0$ \\
\hline $\mathrm{RBC}\left(\times 10^{4} / \mathrm{mm}^{3}\right)$ & 495 & $\operatorname{ALP}(\mathrm{U} / l)$ & 212 & $\mathrm{IA}-2 \mathrm{Ab}(\mathrm{U} / \mathrm{m} l)$ & $<0.6$ \\
\hline $\mathrm{Hb}(\mathrm{g} / \mathrm{d} l)$ & 14.3 & $\mathrm{CK}(\mathrm{U} / l)$ & 38 & Glucagon load test & \\
\hline Hct $(\%)$ & 43.0 & LDL-C (mg/d $l)$ & 101 & Fasting CPR (ng/ml) & 0.07 \\
\hline $\operatorname{PLT}\left(\times 10^{4} / \mathrm{mm}^{3}\right)$ & 20.9 & $\mathrm{TG}(\mathrm{mg} / \mathrm{d} l)$ & 40 & After 6 minutes CPR $(\mathrm{ng} / \mathrm{m} l)$ & 0.10 \\
\hline Urine & & HDL-C (mg/d $l)$ & 42 & delta CPR (ng/ml) & 0.03 \\
\hline $\mathrm{pH}$ & 5.5 & BUN (mg/dl) & 4 & CPR index & 0.06 \\
\hline glucose & $(4+)$ & $\mathrm{Cr}(\mathrm{mg} / \mathrm{d} l)$ & 0.32 & Thyroid-related & \\
\hline protein & $(1+)$ & eGFR (ml/min) & 189.7 & $\mathrm{TSH}(\mu \mathrm{IU} / \mathrm{m} l)$ & 2.28 \\
\hline ketone & $(3+)$ & $\mathrm{Na}(\mathrm{mEq} / \mathrm{m} l)$ & 131 & FT3 $(\mathrm{pg} / \mathrm{m} l)$ & 1.40 \\
\hline O.B. & $(1+)$ & $\mathrm{K}(\mathrm{mEq} / \mathrm{m} l)$ & 3.6 & $\mathrm{FT} 4$ (ng/d $l)$ & 0.90 \\
\hline $24 \mathrm{~h} \mathrm{CCr}(\mathrm{m} l / \mathrm{min})$ & 142.0 & $\mathrm{Cl}(\mathrm{mEq} / \mathrm{m} l)$ & 105 & $\mathrm{TG}-\mathrm{Ab}(\mathrm{U} / \mathrm{m} l)(<28.0)$ & 33 \\
\hline VBG & & $\mathrm{UA}(\mathrm{mg} / \mathrm{d} l)$ & 3.1 & $\mathrm{TPO}-\mathrm{Ab}(\mathrm{U} / \mathrm{m} l)(<16.0)^{\natural}$ & 18 \\
\hline $\mathrm{pH}$ & 7.177 & Amylase (U/l) & 27 & HLA-DNA typing & \\
\hline $\mathrm{PCO}_{2}$ (Torr) & 25 & Lipase $(\mathrm{U} / l)$ & 46 & DRB1*04: 05 & \\
\hline $\mathrm{PO}_{2}$ (Torr) & 44 & & & DQB1*04: 01 & \\
\hline $\mathrm{BE}(\mathrm{mEq} / l)$ & -17.6 & & & & \\
\hline $\mathrm{HCO} 3-(\mathrm{mEq} / \mathrm{l})$ & 9.1 & & & & \\
\hline
\end{tabular}

I: normal range, $\mathrm{CBC}$ : complete blood count, WBC: white blood cell, RBC: red blood cell, Hb: hemoglobin, Hct: hematocrit, PLT: platelet, pH: potential hydrogen, O.B.: occult blood, CCr: creatinine clearance, VBG: venous blood gas, BE: base excess, TP: total protein, Alb: albumin, AST: aspartate aminotransferase, ALT: alanine transaminase, $\gamma$-GTP: $\gamma$-glutamyl transpeptidase, LDH: lactate dehydrogenase, ALP: alkaline phosphatase, CK: creatine kinase, LDL-C: low density lipoprotein cholesterol, TG: triglyceride, HDL-C: high density lipoprotein cholesterol, BUN: blood urea nitrogen, Cr: creatinine, eGFR: estimated glomerular filtration rate, Na: sodium, K: potassium, $\mathrm{Cl}$ : chloride, FPG: fasting plasma glucose, PPG: postprandial plasma glucose, HbAlc: hemoglobin A1c, CPR: C peptide immunoreactivity, ACR: albumin-creatinine ratio, GAD: glutamic acid decarboxylase, IA-2: insulinoma-associated antigen-2, TSH: thyroid stimulating hormone, FT3: free triiodothyronine, FT4: free thyroxine, TG-Ab: thyroglobulin antibody, TPO-Ab: thyroid peroxidase antibody. 
HbA1c of $9.6 \%$ at the time of hospital admission (a rapid increase from $5.4 \%$ measured two weeks earlier). Both urinary C-peptide immunoreactivity (CPR) and serum CPR were significantly low, and insulin secretion was also low on the glucagon loading test. Both anti-GAD and insulinoma-associated antigen-2 (IA-2) autoantibodies were negative, and the human leukocyte antigen (HLA) typing was DRB1*04:05 and DQB1*04:01, which is a typical HLA type for Japanese FT1D [4]. Abdominal CT taken earlier before admission to our hospital showed diffuse enlargement of the pancreas (no ascitic fluid retention or necrosis). However, a repeat $\mathrm{CT}$ on hospitalization showed a relative improvement of the pancreatic enlargement. All the essential items of the 2012 FT1D diagnostic criteria were satisfied, based on the presentation at both hospitals. Furthermore, the high levels of exocrine pancreatic enzymes and CT-based pancreatic enlargement added support to the diagnosis of FT1D.

DKA improved following intravenous administration of saline and continuous intravenous infusion of insulin. On day 2 of admission, DKA showed further improvement with $\mathrm{pH}=7.364$, allowing oral feeding and switching from intravenous to subcutaneous injection of insulin. Finally, her blood glucose level was controlled with insulin degludec: $14-0-2 \mathrm{u}$ and insulin lispro (carbo-insulin ratio (6-12-11) $\mathrm{g} / \mathrm{u}$ ), and she was discharged on day 14.

An analysis of peripheral blood lymphocyte phenotype was conducted during hospitalization using an 8-color flow cytometer. Briefly, the cells were washed with phosphate-buffered saline and analyzed with a FACSVerse (BD Pharmingen, San Diego, CA) and FlowJo software (Tree Star, Ashland, OR). Background fluorescence was assessed using appropriate isotype- and fluorochrome-matched control monoclonal antibodies (BD Biosciences, San Jose, CA). An analysis of CD4-positive $\mathrm{T}$ cells showed high percentages of effector T cells and central memory $\mathrm{T}$ cells relative to those of a healthy age-matched control group of 19 females (mean age: $33.6 \pm 4.3$ years) (Fig. 1 and Table 2). On the other hand, no abnormality was found in CD8-positive T cells (cytotoxic T cells), and there were no differences between the patient and the healthy control group with regard to helper $\mathrm{T}$ cell subsets, such as $\mathrm{T}$ helper 1 (Th1), T helper 17 (Th17), regulatory $\mathrm{T}$
(Treg) and T follicular helper (Tfh). An analysis of B cell differentiation, however, showed high proportions of switched memory B cells and plasmablasts compared to the healthy control group.
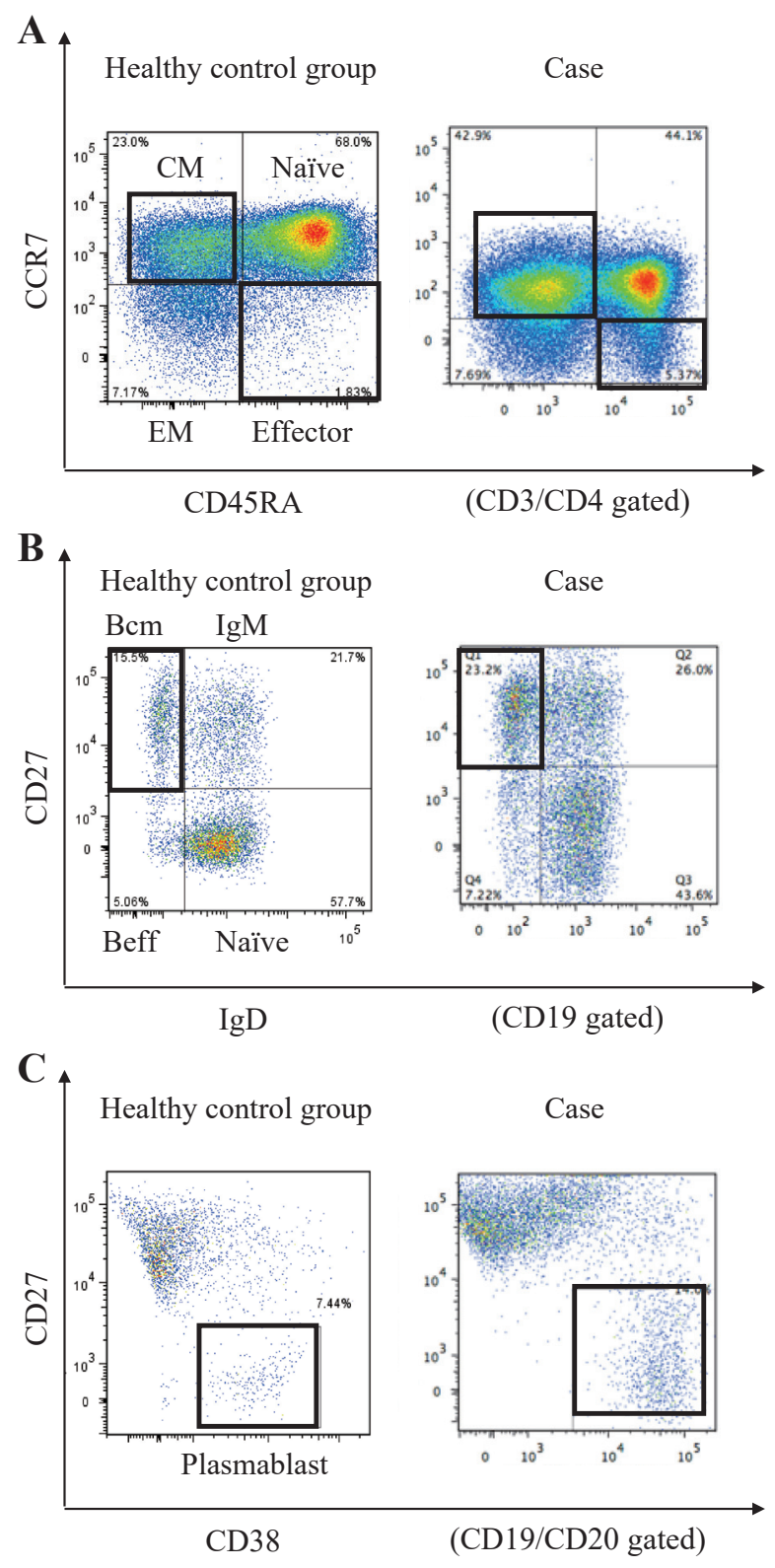

Fig. 1. Analysis of peripheral blood lymphocyte phenotype by using an 8-color flow cytometer. A: Analysis of CD4-positive T cells showed high proportions of effector $\mathrm{T}$ cells and central memory $\mathrm{T}$ cells compared to the healthy control group. B, C: Analysis of B cell differentiation showed high proportions of switched memory B cells and plasmablasts compared to the healthy control group. Bcm: class switched memory B cell, Beff: effector B cell, CM: central memory, EM: effector memory. 
Table 2. FACS data of healthy group and our patient

\begin{tabular}{lll}
\hline & Healthy group & Our patient \\
\hline Effector T cells (\%) & $1.7 \pm 1.1$ & 5.37 \\
Effector memory T cells (\%) & $10.3 \pm 4.8$ & 7.69 \\
Central memory T cells (\%) & $32.7 \pm 6.0$ & 42.9 \\
Naïve T cells (\%) & $55.3 \pm 7.7$ & 44.1 \\
Activated T cells (\%) & $4.4 \pm 1.9$ & 3.56 \\
Th1 cells (\%) & $19.2 \pm 4.1$ & 22.7 \\
Activated Th1 cells (\%) & $1.2 \pm 0.6$ & 1.07 \\
Th17 cells (\%) & $10.8 \pm 3.4$ & 8.97 \\
Activated Th17 cells (\%) & $0.8 \pm 0.6$ & 0.42 \\
Treg cells (\%) & $4.5 \pm 1.2$ & 5.50 \\
Activated Treg cells (\%) & $1.1 \pm 0.6$ & 0.88 \\
Naïve Treg cells (\%) & $1.6 \pm 0.9$ & 1.84 \\
Memory Treg cells (\%) & $2.8 \pm 1.1$ & 3.68 \\
Tfh (\%) & $0.8 \pm 0.4$ & 0.83 \\
Activated Tfh (\%) & $0.17 \pm 0.10$ & 0.09 \\
Effector B cells (\%) & $6.1 \pm 1.8$ & 7.22 \\
Switched memory B cells (\%) & $16.5 \pm 5.4$ & 23.2 \\
IgM memory B cells (\%) & $25.6 \pm 6.1$ & 26.0 \\
Naïve B cells (\%) & $51.8 \pm 10.1$ & 43.6 \\
Plasmablast (\%) & $3.6 \pm 4.1$ & 8.00 \\
\hline FAc $\%$ (\% $\%$
\end{tabular}

FACS: fluorescence-activated cell sorter, Th1: T helper 1, Th17: $\mathrm{T}$ helper 17, Treg: regulatory $\mathrm{T}, \mathrm{Tfh}$ : $\mathrm{T}$ follicular helper, $\mathrm{IgM}$ : immunoglobulin M

\section{Discussion}

We described a case of typical FT1D, but the lymphocyte analysis performed during hospitalization showed abnormal differentiation of CD4-positive $\mathrm{T}$ and $\mathrm{B}$ cells, which, unlike previous reports [3], suggests a diversity in lymphocyte phenotypes in the pathology of FT1D.

Aida et al used immunohistochemical examination of pancreatic lesions to demonstrate the accumulation of macrophages and CD8-positive T cells in and around the pancreatic islets in an autopsy of FT1D case [3]. Similarly, in a study conducted by Tanaka et al, pancreatic tissues from a FT1D patient showed islet inflammation associated with CD8-positive T cell accumulation (with presence of a few CD4-positive $\mathrm{T}$ cells) [5]. In contrast, Shimada et al reported the presence of a high proportion of GAD-reactive interferon- gamma (IFN- $\gamma$ )-producing CD4-positive T cells in the peripheral blood of FT1D [6]. Other studies have reported reduced expression of forkhead box P3 (Foxp3), a master transcription factor of Treg cell, in the peripheral blood of FT1D [7], along with decreased Treg function [8]. To our knowledge, however, there is no report of abnormal B cell differentiation in FT1D.

Kobayashi et al reported high proportions of both anti-amylase $\alpha$-2A antibody and heat shock protein 10 (HSP10) antibody, which were detected in the screening of sera of FT1D patients with autoimmune pancreatitis using complementary deoxyribonucleic acid (cDNA) library of human pancreas [9]. Patients with autoimmune type 1 diabetes are also known to have variable levels of these antibodies, indicating a common predisposition to the mechanisms underlying the development of FT1D and autoimmune pancreatitis, fueling anticipation that these antibodies could be potentially useful in the diagnosis of FT1D.

In our patient, the effector and central memory $\mathrm{T}$ cells among CD4-positive $\mathrm{T}$ cells tended to be higher than the control group, Treg cells were within the normal range, and switched memory B cells and plasmablasts among B cells were higher. These findings are different from previous reports on FT1D, and suggest a diversity in FT1D pathology. Admittedly, the significance of the findings described in this report is limited due to the lack of examination of pancreatic tissues and the inclusion of only a single case. Further case studies are needed to confirm these findings.

\section{Acknowledgments}

The authors thank Ms.N Sakaguchi for the excellent technical assistance.

\section{Conflict of Interest}

The authors declare no conflict of interest.

\section{References}

1. Imagawa A, Hanafusa T, Miyagawa $J$ \& Matsuzawa Y (2000): A novel subtype of type 1 diabetes mellitus characterized by a rapid onset and an absence of diabetes-related antibodies. Osaka IDDM Study Group. N 
Engl J Med 342: 301-307

2. Hanafusa $T \&$ Imagawa A (2007): Fulminant type 1 diabetes: A novel clinical entity requiring special attention by all medical practitioners. Nat Clin Pract Endocrinol Metab 3: 36-45

3. Aida K, Nishida Y, Tanaka S et al (2011): RIG-I- and MDA5-initiated innate immunity linked with adaptive immunity accelerates beta-cell death in fulminant type 1 diabetes. Diabetes 60: 884-889

4. Kawabata Y, Ikegami H, Kawaguchi Y, Fujisawa T, Shintani M, Ono M, Nishino M, Uchigata Y, Lee I \& Ogihara T (2002): Asian-specific HLA haplotypes reveal heterogeneity of the contribution of HLA-DR and -DQ haplotypes to susceptibility to type 1 diabetes. Diabetes 51: 545-551

5. Tanaka S, Kobayashi T \& Momotsu T (2000): A novel subtype of type 1 diabetes mellitus. N Engl J Med 342: 1835-1837

6. Shimada A, Morimoto J, Kodama K, Oikawa Y, Irie
J, Nakagawa Y, Narumi S \& Saruta T (2002): T-cellmediated autoimmunity may be involved in fulminant type 1 diabetes. Diabetes Care 25: 635-636

7. Kobayashi T, Nishida Y, Tanaka S \& Aida K (2011): Pathological changes in the pancreas of fulminant type 1 diabetes and slowly progressive insulin-dependent diabetes mellitus (SPIDDM): Innate immunity in fulminant type 1 diabetes and SPIDDM. Diabetes Metab Res Rev 27: 965-970

8. Wang Z, Zheng Y, Hou C, Yang L, Li X, Lin J, Huang G, Lu Q, Wang CY \& Zhou Z (2013): DNA methylation impairs TLR9 induced Foxp3 expression by attenuating IRF-7 binding activity in fulminant type 1 diabetes. J Autoimmun 41: 50-59

9. Takizawa S, Endo T, Wanjia X, Tanaka S, Takahashi M \& Kobayashi T (2009): HSP 10 is a new autoantigen in both autoimmune pancreatitis and fulminant type 1 diabetes. Biochem Biophys Res Commun 386: 192-196 
末梢血リンパ球の多様性が推測された劇症1型糖尿病の1症例

黒住 旭, 岡田 洋右, 宮崎 佑介, 中山田 真吾, 田中 良哉

産業医科大学 医学部 第 1 内科学講座

要旨：症例は 29 歳女性で, 当院に糖尿病性ケトアシドーシスを伴った劇症 1 型糖尿病に対する加療のため入 院となった. 8カラーフローサイトメーターを用いて末梢血リンパ球の表現型の解析を行った. 健常者対照群と比 較して, 本症例は CD4 陽性 $\mathrm{T}$ 細胞については effector T 細胞や central memory $\mathrm{T}$ 細胞が増加傾向で regulatory $\mathrm{T}$ (Treg) 細 胞は正常であった。ささらに, B細胞分化では対照群と比較して, switched memory B 細胞と plasmablastの割合の増加を 認めた。本症例は末梢血リンパ球解析において既報とは異なった特徵を認め, 劇症 1 型糖尿病病態における末梢血り ンパ球表現型の多様性が示唆された.

キーワード：劇症 1 型糖尿病, フローサイトメトリー, 末梢血リンパ球.

J UOEH(産業医大誌) 42(1)：57 - 62 (2020) 